\title{
Photographs of the interpreters of the Indian Protection Service - SPI (1910 - 1967)
}

Helena Lúcia Silveira Barbosa e John Milton*

\section{The Photographic Archive of the Indian Protection Service - SPI}

The work developed by the National Indian Foundation - FUNAI [Fundação Nacional do Índio] was formerly developed by the SPI, the previous official institution responsible for coordinating and executing the federal indigenist policies of the Brazilian government and for protecting and promoting the rights of the indigenous peoples in Brazil.

The SPI was created in 1910 to intervene in the conflicts that took place during the colonization of the west of the São Paulo state, which occurred with intense brutality towards the indigenous peoples of the region ${ }^{1}$. Marechal Cândido Rondon was invited to organize the SPI due to his experience in expeditions in the Brazilian hinterlands acquired during the activities of the Rondon Commission, which was a 15-year project that aimed to link the federal capital at the time, Rio de Janeiro, to the remote northern and western areas of Brazil via telegraph lines. Instead of extinction and the genocide of the indigenous peoples, Rondon advocated a policy of pacification reinforced by the motto "To die if necessary; to kill, never" (Rocha Freire 2010, p. 11).

\footnotetext{
${ }^{*}$ Universidade de São Paulo (USP).

${ }^{1}$ The SPI, in fact, was born as the Service of Protection to the Indians and Localization of National Workers - SPILTN [Serviço de Proteção aos Índios e Localização dos Trabalhadores Nacionais], but in 1918 an administrative reform took away from it the assignment of "Localization of National Workers", passing it to another organ.

${ }^{2}$ Morrer se preciso for; matar, nunca.
} 
The great majority of the official SPI photos, specially those published in Memória do SPI: textos, imagens e documentos sobre o Serviço de Proteção aos Índios (1910-1967), reflect the policy of the SPI under Marechal Rondon to integrate the indigenous groups into Brazilian society as rural agricultural workers and to lose their Indianness, seen as inevitable by the positivist ideas of Rondon. By learning the colonizer's way of life, customs, religion and language, they would be presented with the advantages of "civilization" and would eventually fend for themselves.

This would be the solution for the genocide of many indigenous groups, including the Xetá, as we shall see in this article. Thus, the photos we see in Memória do SPI are of school groups, indigenous persons working as agricultural labourers, girls in sewing groups, people playing football, all well-behaved and clothed and integrated seamlessly into the lower rungs of Brazilian society. Essentially colonial photos, a "showcase" of the State intervention into the situation of indigenous groups, as pointed by Freire (2011, p. 17).

Indeed, we have to delve into the carefully produced and well-illustrated book in order to find a picture of unclothed, sick or malnourished indigenous men and women. And then it seems as if these photos are of the misfits, the latecomers, the groups who have missed the bus and will soon take their place at the hoe, in the scullery, or at the sewing machine. The SPI's image archive, therefore, focuses on the progressive project of the Brazilian State and hides an existing reality of suffering and disputes.

But in the broad collection of the SPI archive we can find a number of pictures of interpreters, some of which defy the official position of the SPI, and by looking more deeply into others, finding the punctum, Barthes ([1980] 2015) term for the disconcerting element in a studium, a study of a theme, here the success of the SPI in integrating the Brazilian Indians into Brazilian society. In this article we study a number of these photographs, which show the contrasting elements of the SPI and its interpreters. 


\section{Why study photographs of interpreters?}

Why study photographs of interpreters? An initial answer is that for translation and interpretation scholars there are far more photographs available of interpreters than translators, and the interpersonal, often public, relationship involved in interpreting, particularly up until the advent of simultaneous interpreting, makes such photographs an attractive option for study, compared, say, to a translator in their study or at their computer. Another reason is that there are now a vast number of photographs available on the Internet, making it possible to find photographs of interpreters and make such studies possible from the comfort of one's home or office. Indeed, the Museu do Índio in Rio de Janeiro has made an enormous archive of photos available on its website, from which all but one of the photos studied here were taken.

What then, can photographs of interpreters show us? The photograph captures a moment in time, making a historical record, showing past customs and habits: class stratification; sartorial habits; distance and/or closeness between human beings, and how one society looks both at itself and at another in terms of friendship and/or hostility. Our photographs will give us an idea of the relations between the Xetá boy interpreters Tuca and Kauiá and those they were interpreting for in 1955; the tense situation of the first peaceful contact with the Xavantes in 1949; an apparently happy Darcy Ribeiro obtaining information through his interpreter João Carvalho from a Ka'apor woman in 1951; and the contrasting pictures of the Kaingang Chief, Vegnon, who also worked as a scout for the SPI from 1910 to 1912.

The study follows on from the groundbreaking work of Framing the Interpreter: Towards a visual perspective, edited by Anxo Fernández-Ocampo and Michaela Wolf (Routledge 2014), and we can see some of the themes reappearing in this study. Several of the articles in Framing the Interpreter stress the isolation of the interpreter; the articles are grouped around the themes of "Colonial Exposures", the "First World War", the "Second World War", and the "Cold War". A number of the interpreters portrayed, seen as traitors to their native society, were soon to die after being photographed. Here we also show displaced persons who belong to societies that have been, 
are being and will be invaded and ripped apart in the insatiable thirst for land and "development".

In addition to examining the photographs as historical documents, their visual grammar and syntax will also be analysed, often following on from Krees and van Leeuwen (2006).

\section{Tuca and Kaiuá, the Interpreters of the Xetá Expeditions}

\section{Photograph 1: Sweaty Blokes in the Forest (1955)}

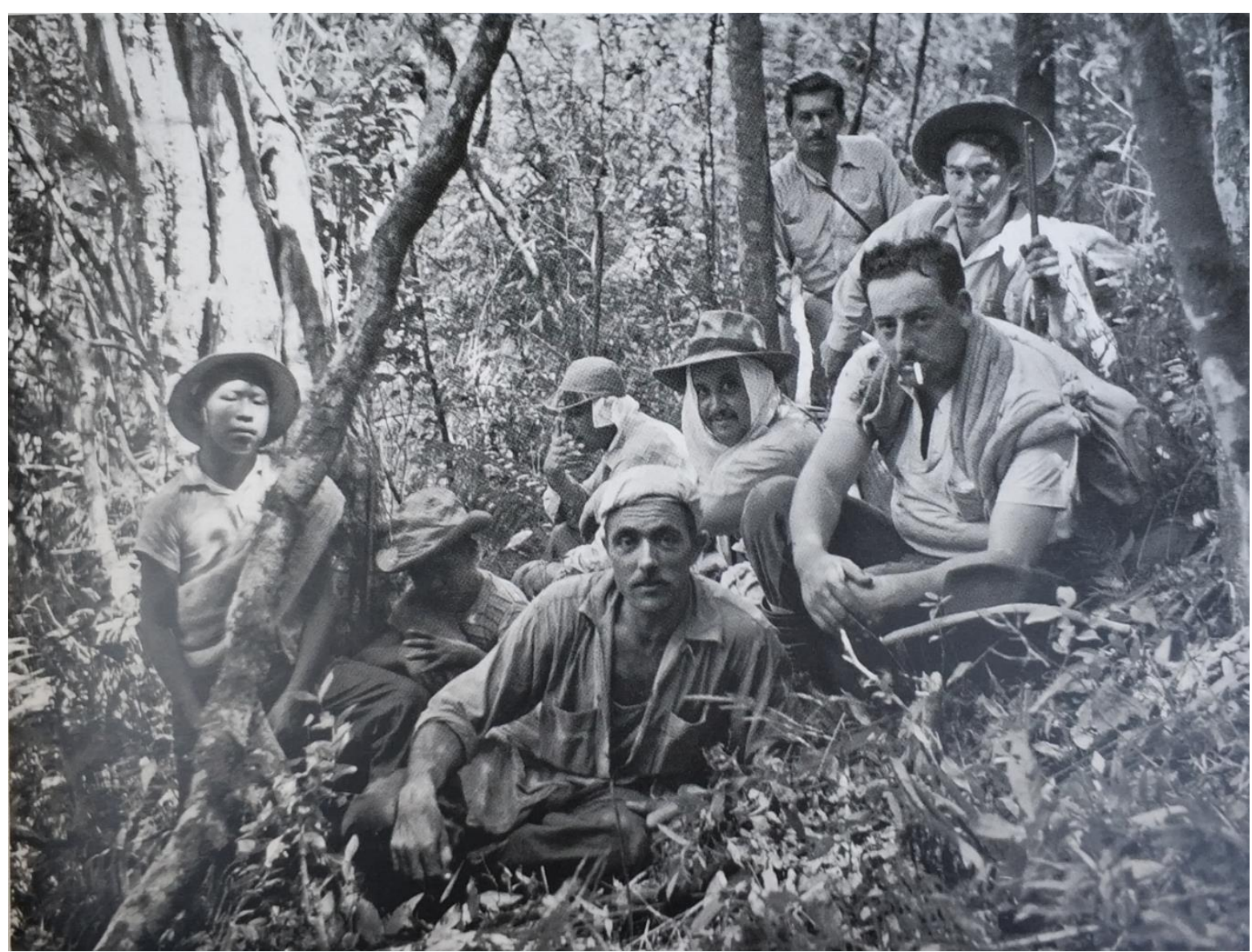

Caption: Rest stop of the Xetá attraction expedition in Serra de Dourados, state of Paraná, 1956. Photo: unkown. Museu do Índio collection. 
In October 1955 an expedition has been formed by the SPI to search for the Xetá, some of whom have appeared on the Santa Rosa Farm. Here the expedition is stopping for a welcome break to rest and smoke. They are looking straight into the camera, at least the main players in the expedition, the three "blokes" at the centre of the photo: with his handkerchief on his head, Antônio Lustosa de Freitas, the owner of the Santa Rosa Farm, which had been part of a larger area owned by his uncle, the state deputy Antônio Lustosa de Oliveira; José Loureiro Fernandes (1903-1977), Professor of Anthropology at the University of Paraná; and to his left, Dival José de Souza Nenê (1925-2005), employee of the SPI. Although other photos show that Loureiro is much shorter than Lustosa and Dival, here, seated on the ground, they look remarkably alike: Latin Portuguese/Spanish features, dark hair, moustache, corpulent, pudgy, sweaty, out of place in the forest, and suffering. There is a clear hierarchy. The sweaty blokes form an inner circle, outside of which are the two Xetá indigenous boys, Tuca, nine years-old, and Kaiuá, forming one group on our left, and the other group of scattered individuals: Loyola Neto, the journalist, smoking in the background; the photographer Ferralma; and the one figure to look calm, cool, and at ease, the student Ney Barreto, who seem to have little to do with each other. Although the boys have been taken away from their families and are now living in the house of the father of Dival, they seem to have very little contact with any of the white men, and certainly there is no substitute father - sons relationship.

The photo has something of the holiday photo, or perhaps the choice of the wrong holiday. Lustosa's handkerchief on his head to soak up the sweat reminds me of the standard working class beachwear in the 1960s (writes John Milton). Few British men would own or need a sunhat, and the solution to the occasional hot day at the beach was to protect one's scalp with a cloth handkerchief, very similar to that of Lustosa.

This impression that the photo gives may be contrasted with the actual situation and perhaps gives us a false impression. The three "blokes", though with the superficial physical similarities remarked on above, come from contrastingly different backgrounds, and had very different roles to play in the problem of the Xetá. Antônio Lustosa de Freitas' uncle, Antônio Lustosa de Oliveira, had received from the state government a large amount 
of the land on which the Xetá had been living, and a part of this was given to his nephew. Lustosa de Freitas was one of the first people to come to the area in 1952 when his uncle asked him to look after his land, and he brought 22 farm workers to clear the land. His uncle gave him 55 hectares, which became the Santa Rosa Farm. Indeed, his son Luiz Carlos Alves de Freitas was the first person to be born in what is now the municipality of Douradina. He later took part in local politics for the Social Democratic Party (PSD) and was a State Deputy and Mayor of Douradina. Despite, or maybe because of, taking over the lands which had belonged to the Xetá people, the Lustosas seems to have shared a concern for the welfare of the Xetá. In 1955 Lustosa de Freitas' uncle, Antônio Lustosa de Oliveira, a state deputy, proposed that a Xetá indigenous reserve should be established, and Lustosa de Freitas was an active participant in the expeditions.

José Loureiro Fernandes was Professor of Anthropology at the University of Paraná. He had originally trained as a doctor in Paris. He worked at the Museu Paranaense, coordinating the area of Anthropology and Ethnography, and was director from 1936 to 1943 and from 1945 to 1946. He also directed the Archaeological Studies and Research Center - Cepa, created in 1956, and conceived and directed the Museum of Archeology and Ethnology of UFPR - MAE, located in the city of Paranaguá. He published widely and was responsible for training a large number of specialists in the area.

Dival José de Souza was a career SPI employee and supported the cause of the Xetá people and battled against the big logging and industrial agricultural companies. He graduated as an economist and followed his father, Deocleciano de Souza Nenê, into the SPI, and was later head of the indigenous station in Ibirama, state of Santa Catarina.

\section{The Xetá Indigenous Group}

The Xetá were the last ethnic group in the state of Paraná to have contact with Brazilian society. Their first recorded contact took place on 6 December 1954, when six males, tired of constantly running away from the colonization fronts that had been advancing into their territory since the end of the 1940s reducing it drastically, visited Antônio Lustosa de Freitas' Santa Rosa Farm. 
These men then withdrew to the forest, returning a few days later with their families, including women and children. After that the visits became frequent.

In 1955, upon learning about the direct contact of the Xetá with the inhabitants of the Santa Rosa Farm, the SPI organized two contact expeditions to the area, known as Serra dos Dourados, one in October and another in November. The two photos are from the first expedition. Only the latter was able to find the group that visited the farm.

In February 1956, a research expedition led by José Loureiro Fernandes, of the Federal University of Paraná, found two other villages in the forest. No member of the first Xetá expedition took part in this search; neither were they sighted by subsequent expeditions. No other groups were found afterwards. However, the family that had made contact with the people in the Santa Rosa Farm continued to visit it.

\section{The Interpreters Tuca and Kaiuá}

Tuca, or Tucanambá José Paraná, was captured when he was six years-old by surveyors of the colonization company and the representatives of the SPI when he was picking fruit up a tree in 1953. He was taken to the house of Deocleciano de Souza Nenê, known as Nenê, an Inspector of the SPI, who looked after Tuca in his guest house in Curitiba. There he met Kaiuá, Antônio Guairá Paraná, who had been captured in 1952 (Silva 1998: 45). Tuca began to study but never finished primary school, studying only up to year two. Little by little he began to learn about the life of the "whites" and acquire the necessary skills, working in the guest house. He also looked after Kaiuá, who could never adapt to life outside the forest and hardly learnt Portuguese and couldn't $t$ even wash his clothes. Tuca became a father figure for the other Xetá children living with the whites, the boys, Kuein and Kaiuá, and the girl, Ã. He was baptized, and his godparents were the Governor of the state of Paraná, Moysés Lupion, and his wife. According to Dival, this was apparently a tactic of Lustosa and Nenê to get the support of Lupion for the cause of the Xetá people but was not successful (Silva 1998: 47). Then, from October 
1955, after three years of living with the whites, Tuca was invited to accompany a number of research expeditions, along with Kaiuá, and did so until February 1961.

With the closure of the guest house in Curitiba, he went with Dival to Guarupuava Indigenous Post, where he became Dival's cook. There he met up again with his sister A'ruay, his brother-in-law Eirak and his nephew Tiqüein, in addition to Kuein and Kaiuá. Tuca then went to the Manguerinha Indigenous Post, where he met his first wife, worked in a sawmill, returned to the Guarupuava Indigenous Post, met and separated from his second wife, a Kaingang woman, and then finally met his third wife, with whom he was living in the Rio das Cobras Indian Post, where he worked (Silva 1998: $52)$.

He died aged 61 on 11 June 2007 (Peres 2007), one of the last speakers of the Xetá language. In 1999, the number of Xetá speakers was down to eight, though rather more claimed Xetá descendancy, without being able to speak the language (Povos Indígenas do Brasil, 2019).

\section{Photograph 2: Interpreter at Work (1955)}

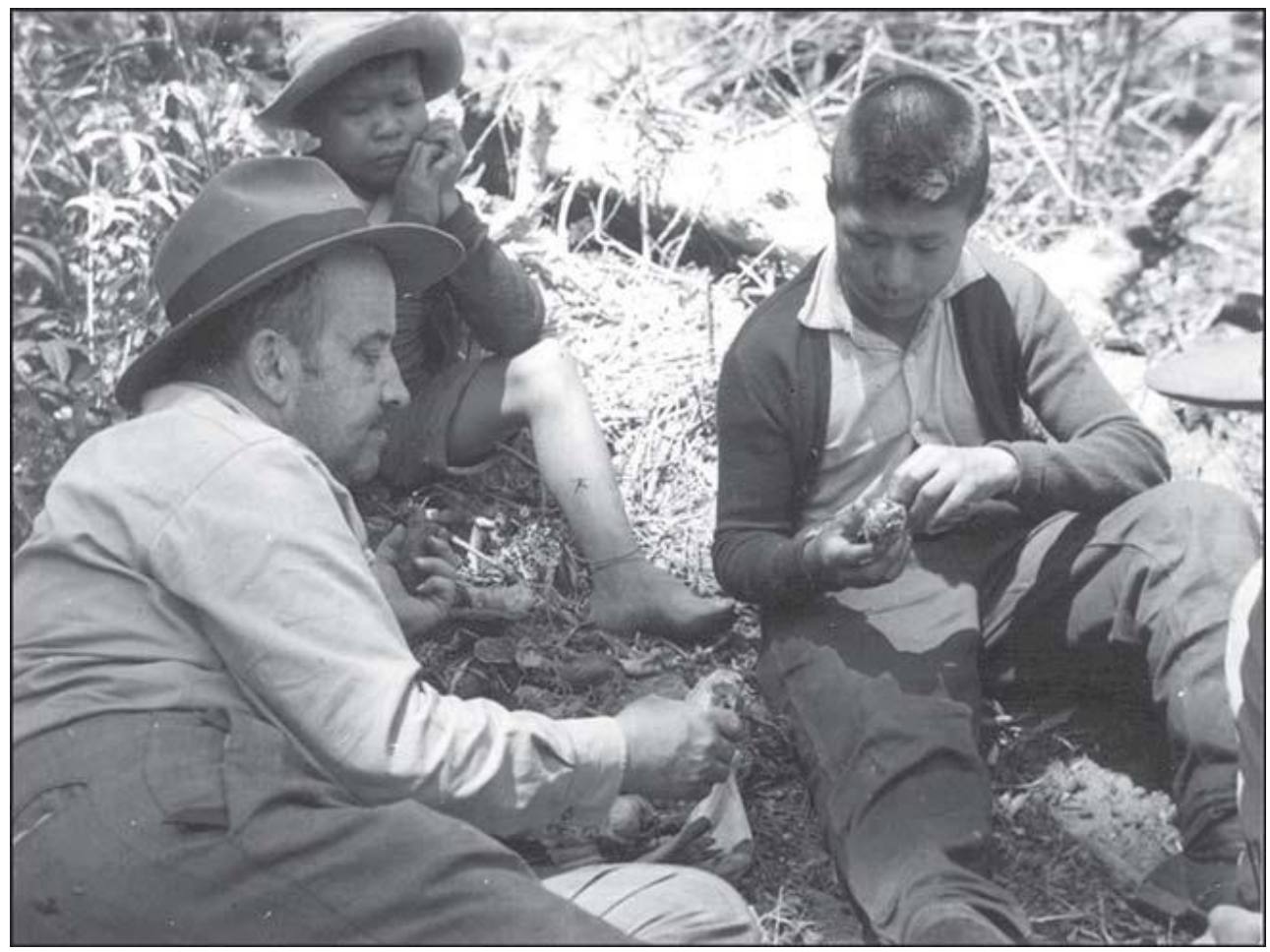


Caption: October 1955, first expedition. Loureiro Fernandes and the boys Tuca and Kaiuá, who help him to identity the artifacts found at the Xetá camp located by the expedition. Photo: Ferralma - MAE/DEAN/UFPR Collection

This photo was also taken during the first Xetá expedition. Here we can see the two young interpreters helping Loureiro Fernandes to identify an artifact found at the Xetá village. Unfortunately, the type of artifact is not clear in the photo; it might be one of the stone tools used by the group and which now form part of the José Loureiro collection at the Universidade de Paraná, Brazil (Merencio 2015).

However, the focus of the picture is not on the object, but on the relational context, on the interaction between Fernandes and the boys, specially Tuca, who is usually the one to take the front of the interpreting situations. Tuca's job was to interpret for any Xetá individuals whom the expedition came across, maybe also as scout, and when they found the abandoned camps, give details on everything they found. He is probably the best interpreter in the expedition team, as he speaks both languages and usually assumes a proactive position, according to the official reports. In the photo, for instance, Tuca is trying his best and seems to remember many things. Again, Kaiuá is distanced, dependent on Tuca's performance.

Hence, Loureiro depends on Tuca as one of the few surviving Xetá speakers, a very difficult task for a 9 year-old boy. Though he may not realize it, this young boy is responsible for communicating details of the Xeta culture, which, without his help, will be lost to posterity. However, the atmosphere is relaxed, and Loureiro seems much more in control of the situation than in the forest, and there seems to be a very positive exchange between him and Tuca. 


\section{Euvaldo, the Interpreter of the Xavante Expedition}

Photograph 3: A Tense Handshake (1949)

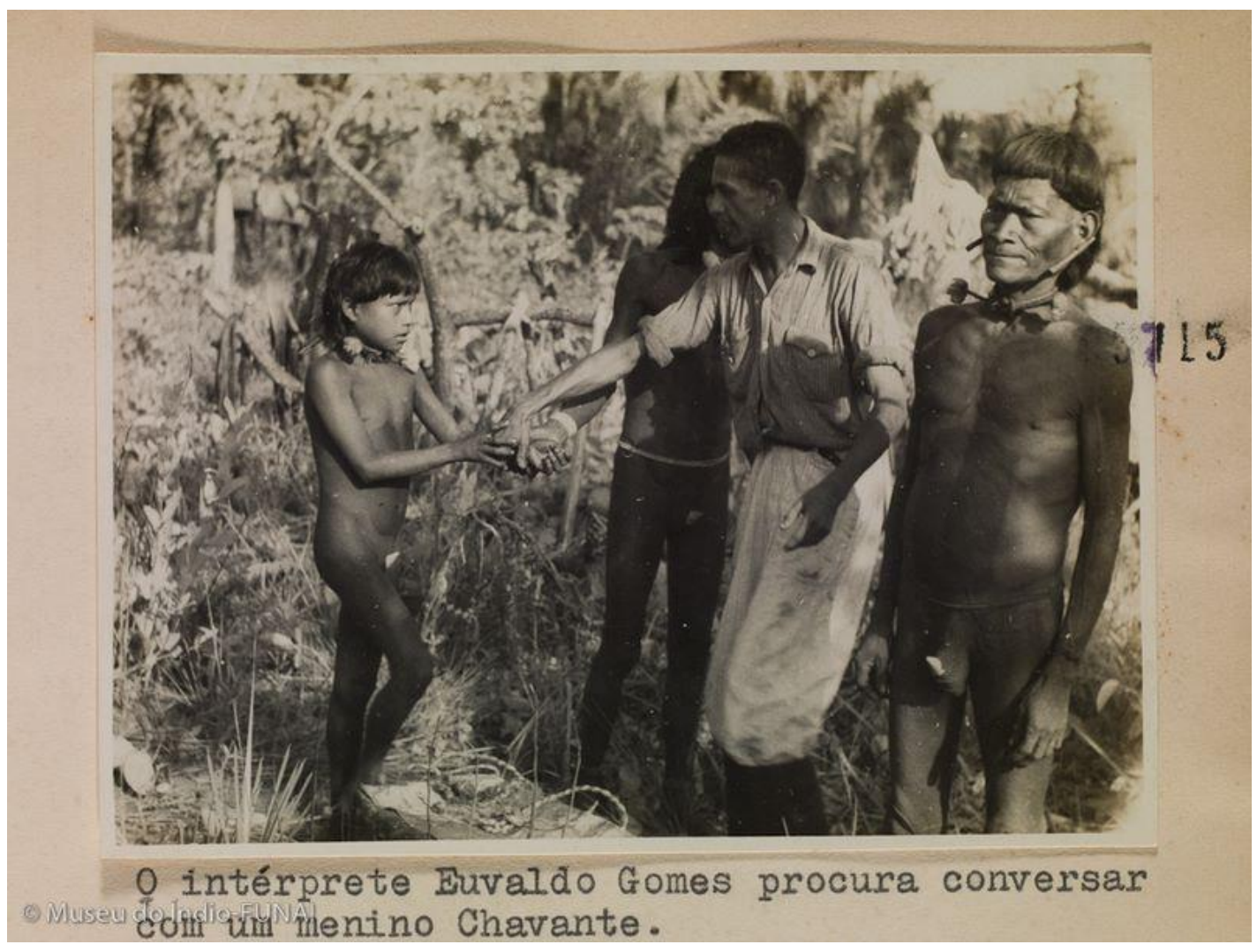

Caption: The interpreter Euvaldo Gomes tries to talk to a Xavante boy. Photo: unknown. Museu do Índio collection.

The attempts at contact with the Xavante people were marked by hostility and violence. The first expedition team, led by the SPI inspector Genésio Pimentel Barbosa, was almost entirely killed by the Xavante in 1941, and only a few workers and the interpreters (who were Xerente natives) managed to escape because they were a distance from the main body of the expedition when the encounter occurred (Freire \& Guran 2010, p. 68). Five years later, a second team was organized, now led by the sertanista Francisco Meirelles, and finally contact was possible. The picture here is from this second expedition. 
Here we see the heightened tension of the situation. On the SPI side, probably caused by the previous violent events and by the reputation of the Xavante people as hostile and ruthless. On the Xavante side, by their long history of conflicts with the government and deaths by disease and war. Distance is kept between all the persons involved, showing that trust is not yet there. It should be noted that the interpreter Euvaldo was not a Ka'apor native; actually, he is not even a native, which may have produced even more mistrust and fear in the Ka'apor individuals in the scene.

Why is Euvaldo talking to the Ka' apor boy and not to the elder? Was he more open, less prejudiced towards the whites? Always a good way to get on the right side of people is to praise their children. The elder (on the right) is actually an ambiguous figure. Is he father or grandfather of the boy? Why isn't he being engaged in conversation? Why isn't he taking part in the scene? Is he on guard in case anything happens? Maybe he suspects the photographer may have a weapon.

Traditionally in Western society the handshake is a symbol of peace and friendship, and here there is a three way handshake, in which the figure in the background, whom we may suppose to also be a member of the SPI party, takes part, and sufficient distance is kept to ensure that no suspicion may be harboured that the left hand may be about to thrust a dagger.

In Western culture we naturally look at visual material from left to right (Kress and van Leeuwen 2006, p. 179-180), so the Xavante boy is the dominant figure in the photograph. One can even read the photograph as a kind of homage being paid to the boy, and of course Western art is replete with portrayals of homage being paid to the baby Jesus in the arms of his mother Mary, who is nearly always on the left-hand side of the picture. 
The Interpreter Vegnon and the Kaingang Pacification

Photograph 4: The Protector of the Natives (1910 - 1912)

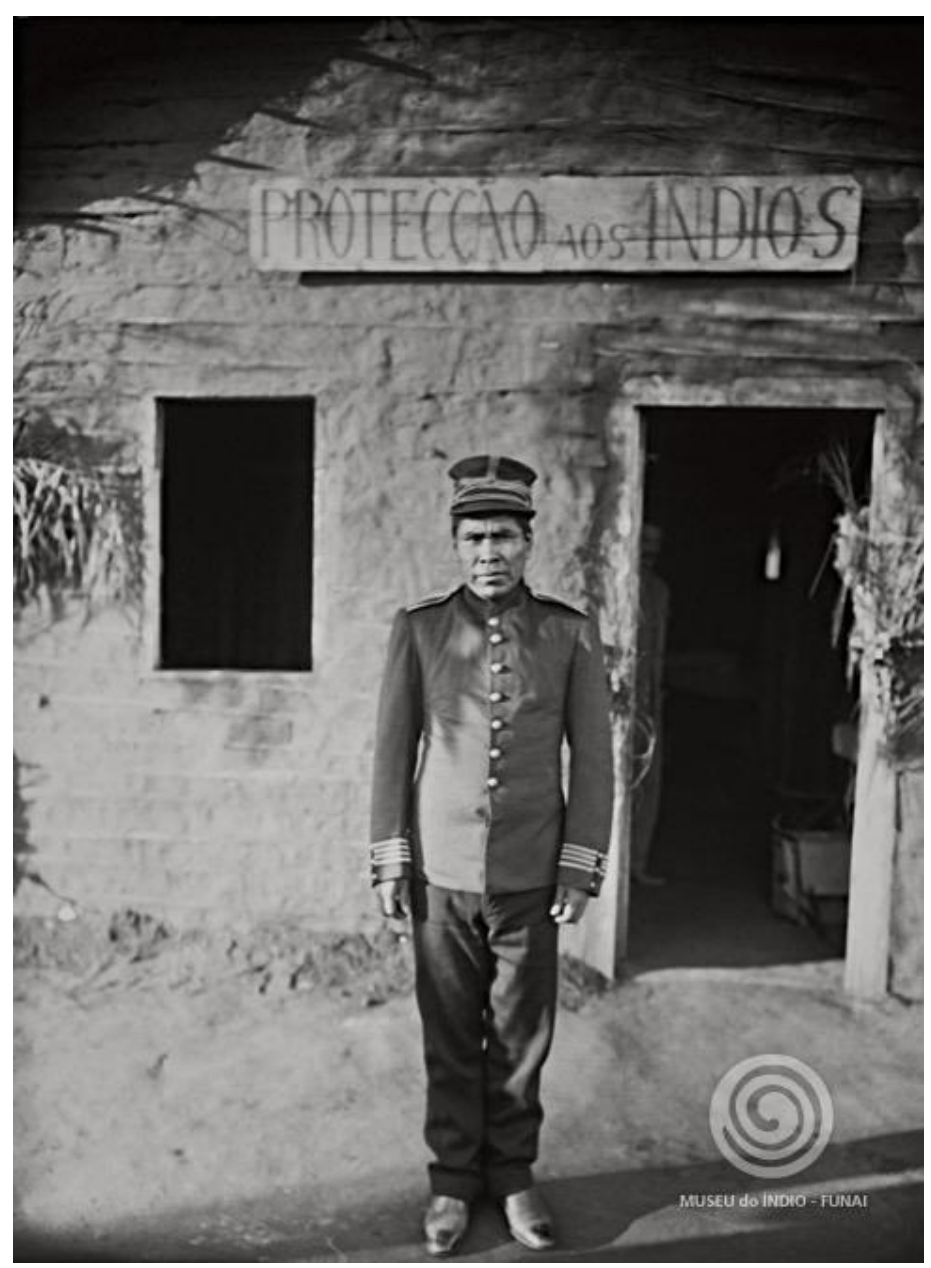

Caption: Chief Vegnon, Kaingang from Paraná, interpreter during the pacification of the Kaingang people. Photo: unknown. Museu do Índio collection.

This photo does not have a date, and the only information given is about Vegnon's origin and that he was an interpreter. The Kaingang Chief Vegnon was one of the interpreters of the attraction team assembled to work in the pacification of the Kaingang of the west of the São Paulo state, which took place from 1910 to 1912. The main interpreter of the expedition was Va- 
nuíre, a Kaingang woman known as the Pacifier because of her amazing mediating qualities and the role she played during the process of contact with the Kaingang. However, even though Vegnon is not given as much attention as Vanuíre in the official reports, he, alongside the interpreter Futoio, were responsible for establishing the first successful communication with Chief Vauhin and other hostile Kaingang natives, which resulted in the clarification of very important information for the pacification process. Right after this, exactly on 19 March 1912, ten Kaingang warriors, including Chief Vauhin, entirely unarmed and naked, approached the camp. Then visits started to be frequent, and peaceful contacts with the Kaingang of the west of the São Paulo state started to be established (Barbosa 1947).

Concerning his place of origin, it is uncertain. As we can see in the picture caption, some scholars say he was from a Kaingang group of Paraná. In the book Memória do SPI, there is the same photo, but the caption describes him as a Terena native, not a Kaingang, wearing a military uniform of the Paraguay war (Freire 2011, p. 168). Most information, however, agree that he as well as Vanuíre and Futoio were brought from São Paulo, specifically from the farm of Aníbal Sodré, where they worked as slaves (Pinheiro 1999, p. 161).

What message does the photo give us? The primitive run down wattle and daub hut hardly seems to offer protection to the indigenous population. It looks like a pretty half-hearted effort on the part of the Brazilian government. Will Vegnon alone protect the Kaingang? Indeed, why is he alone? Can we see him as a traitor to his own Kaingang society like a number of the solitary interpreters portrayed in Framing the Interpreter? Why is he wearing the uniform? He seems to be proud to be wearing his military uniform, but when we discover that the uniform is that of the Brazilian army in the Paraguay War (1864-1870) his patriotic pride takes on a hint of absurdity, and we realize he has been given some discarded leftovers, making him look more like a scarecrow or as if he were going to a fancy dress ball. 


\section{Photograph 5: Discovery of the Settlement (1911)}

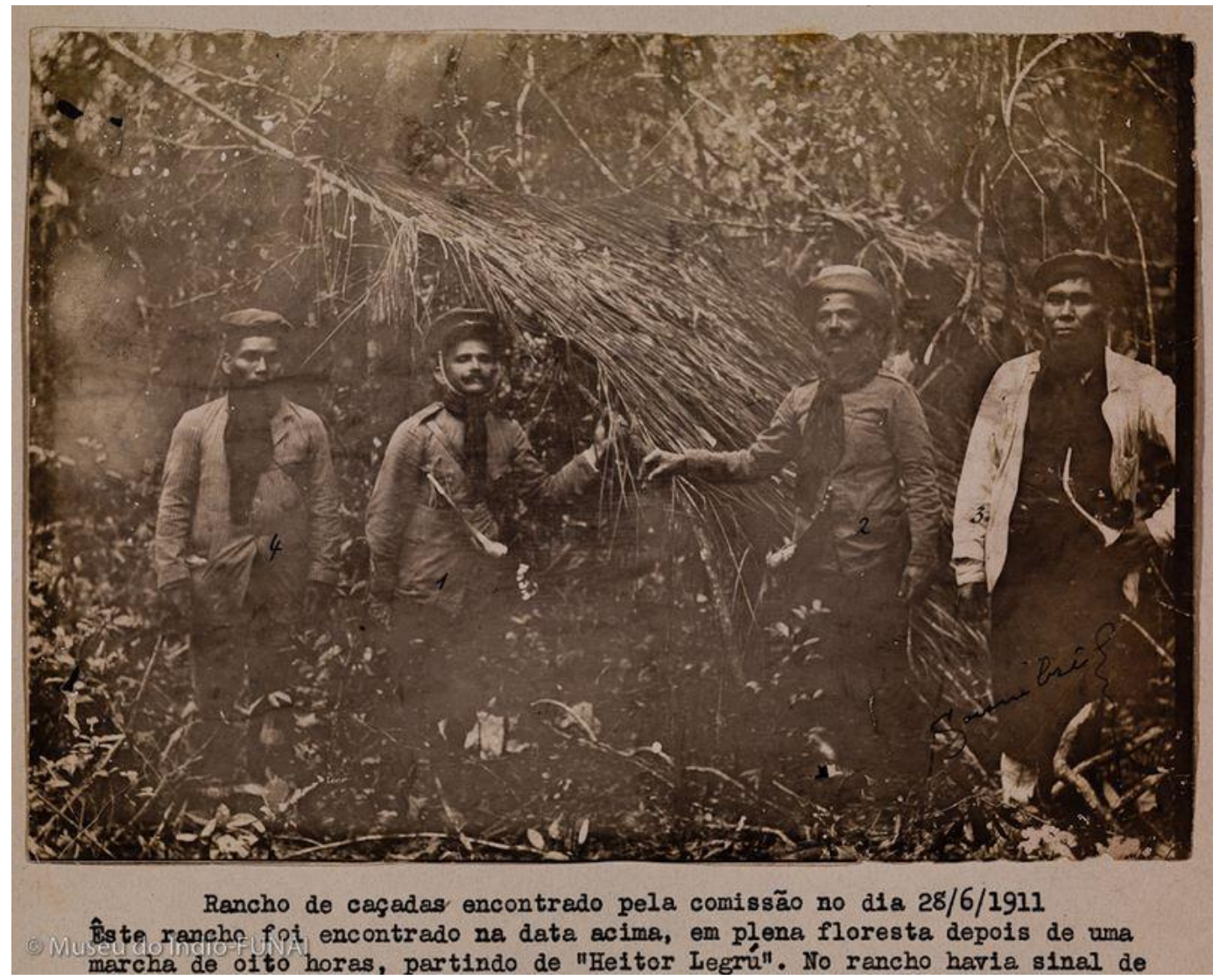

Caption: Game ranch found by the commission on 28 June 1911. This ranch was found on the date above in the forest after an eight-hour walk departing from the "Heitor Legrú" train station [...]. Photo: unknown. Museu do Índio collection.

This photo gives a very different idea of Vegnon. He is the interpreter-scout, who has probably led the SPI group to the rancho. He is looking pretty fresh after his 8-hour hike and has a more confident look than in the previous photo. He is no longer wearing his military uniform and seems to be integrated into the group, with a look of quiet confidence and satisfaction at having successfully completed their task in which he was a central player. 
He's looking much healthier than in the previous photo, where he seems rather shrunk in his uniform and may have been eating much healthier food since then.

\section{The Interpreters of the Ka'apor Expeditions}

\section{Photograph 6: A Good Day at the Office (1951}

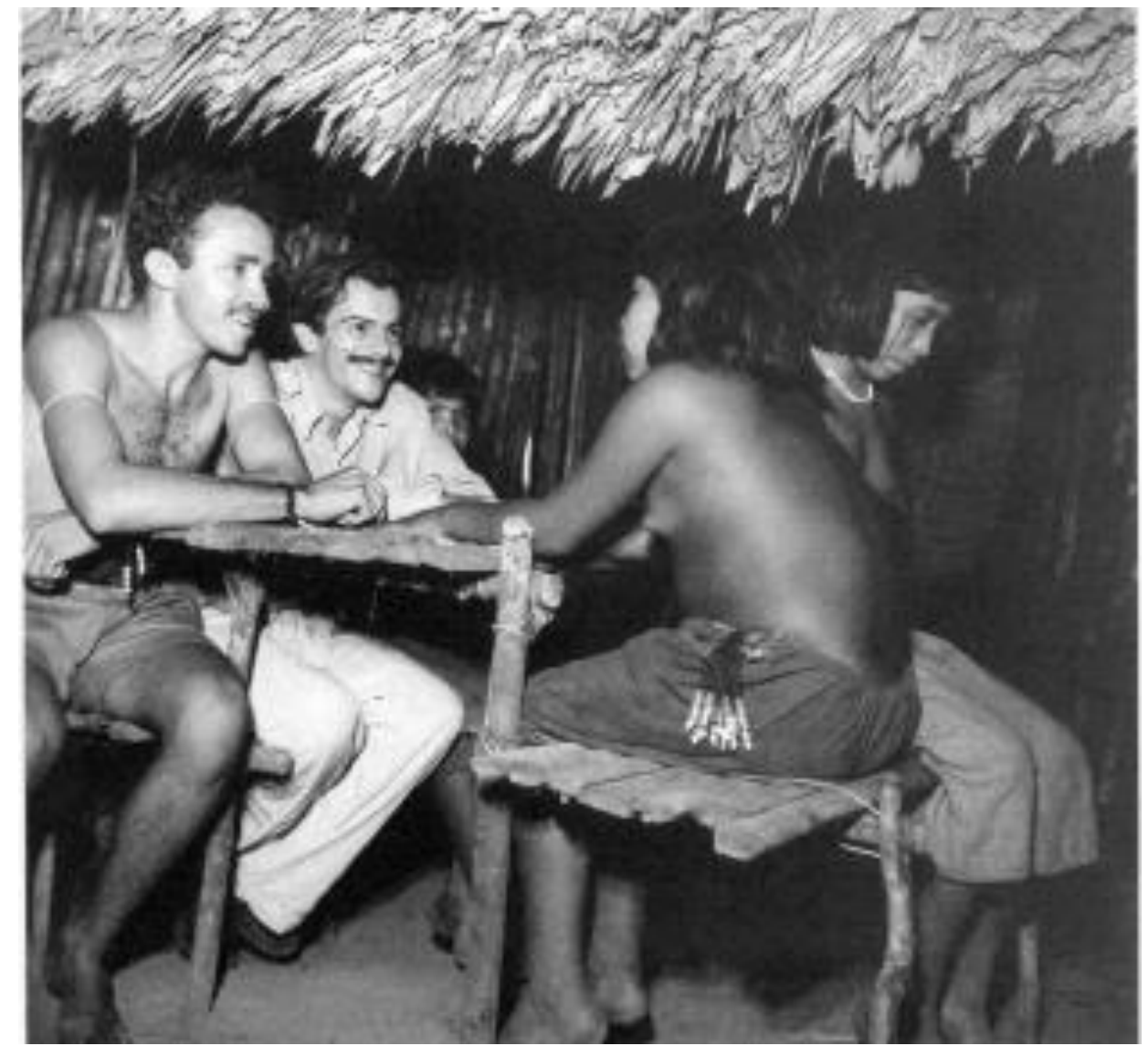

Caption: Darcy Ribeiro and the sertanista João Carvalho talk to Ka'apor women. Gurupi river, state of Maranhão, 1951. Photo: Heinz Förthmann. Museu do Índio collection.

In 1947 Darcy Ribeiro was contracted as a "sociological anthropologist" by the SPI, which had set up a Study Section (SE) in 1942, after the 
Getúlio Vargas dictatorship had decided to invest more heavily and restructure the SPI (Freire 2011, p. 213-214). He wrote Diários Índios on two field trips to the Ka'apor villages located between the Rivers Gurupi and Pindaré, on the border of the states of Pará and Maranhão in 1949 and 1951, although they were only published in 1996, and they contain telling comments about the SPI interpreters.

Darcy had major problems on the first expedition, held from 20 November 1949 to 11 April 1950. Although he had some knowledge of the Ka'apor language (which is a member of the Tupi-Guarani language family, varieties of which were, and still are, spoken in many areas of Brazil, especially in the south), he needed an interpreter who could help him with the details in a number of areas: genealogy, anthropophagy, census making, rituals, work routines, myths and traditional stories, handcrafts, all of which are described throughout the diaries. Apparently initially Darcy had no choice, and was allocated any employee of the SPI who spoke the Tembé language (also from the Tupi-Guarani family) and might welcome the chance of earning extra money for his services. Ideally, the interpreter would have intimate contact with the Ka'apor, be able to get on well with them as a kind of liaison interpreter and also be able to extract from them as many stories and legends as possible, information on kinship and daily habits, should know the area well and at times be prepared to work as an interpreter-guide. The work was often quite complex, requiring very different skills from those needed by the interpreter who would be making contact with an isolated group. As the language had no written form, all interpreting would be oral. The interpreter Darcy was given, Emiliano, a Tembé Indian, who could communicate with the Ka'apor, was an utter failure, thereby restricting the amount of information Darcy could obtain. Later in the first expedition, Darcy meets João Carvalho, a sertanista, whose interpreting skills Darcy admires, and with João Carvalho as regular interpreter, the second expedition, from 2 August 1951 to 9 November 1951, was much more prosperous. João Carvalho successfully communicated information on many topics to Darcy: he gives details of the geography of the Ka'apor territory (Ribeiro 1996, p. 338 / 11 Aug 1951); he knows the indigenous slang (Ribeiro 1996, p. 191 / 8 Feb 1950); he takes on well the responsibility of organizing 
the groups and individuals he will meet and interview (p. 331 / 8 Aug 1951); and as a result of his skills the number of myths that Darcy manages to collect and accurately transcribe on this expedition is much greater. The duties of the interpreter are not exclusively oral as he takes João Carvalho to protect him from the mad dogs (p. 553 / 20 Oct 1952) chasing a captive queixada (wild pig).

Darcy emphasizes the very important role of his interpreter: "João is our interpreter and during these hours of social receptions his role is as important as during those of his work, so he has to speak a lot to make up for my silence" ${ }^{\prime \prime 3}$ (p. 366 / 22 Aug 1951). He admits his frustration at having to use an interpreter but is thankful to João:

\begin{abstract}
How difficult it is to speak through the mouth of someone else, and it's only worse to hear with someone else's ears. I find it so anguishing to hear the Indian speak at length and only get a laconic translation. But I must not complain, João is the best interpreter I've had, and for him my questions and demands, which he can't always understand, are far more agonizing than his worst interpretations for me. ${ }^{4}$ (Ribeiro 1996, p. 367 / 25 Aug 1951).
\end{abstract}

João also entertains by singing traditional songs from the state of Maranhão and those he has learnt from the radio (p. 525-6 / 16 Oct 1951).

On the first journey he mentions the outbreaks of measles, which caused the deaths of many indigenous people, and the poor conditions he was forced to endure. In Piahú, he is in lying in the hammock and writes "Around here there is no table, nor anything that lends itself to writing. The best thing is to keep swinging in someone else's hammock. Mine is in the captain's house, in the midst of all the ill people. This is undoubtedly the place where I have most smelled humanity. What animal stinks more than man?"5 (p. 180 / 4 Feb 1950).

\footnotetext{
${ }^{3}$ João é nosso intérprete e nessas horas de recepções sociais seu papel é tão importante quanto nas de trabalho, de modo que tem de falar muito para compensar meu silêncio.

${ }^{4}$ Como é difícil falar pela boca alheia, só é pior ouvir com ouvidos alheios. Imensa é a angústia de escutar o indio falar longamente e só obter uma tradução lacônica. Mas não devo queixar-me, João é o melhor intérprete que tive, e, para ele minhas perguntas e exigências, que nem sempre pode compreender, são muito mais angustiosas que suas piores interpretações para mim.

${ }^{5}$ Por aqui não há mesa, nem qualquer coisa que se preste para escrever. O melhor é mesmo ficar embalando em rede alheia. A minha está na casa do capitão, no meio de todos doentes. Este é, sem dúvida, o lugar onde mais senti o cheiro de humanidade. Que bicho federá mais que o homem?
} 
And at the village of Ianawakú on the first expedition: "The mosquitoes also torment me, it is a torture, my whole body is already marked. Even swellings in the groin, which after much concern I found to be a consequence of so many insect bites" ${ }^{\prime 6}$ (p. 126 / 7 Jan 1950).

However, on the second expedition he visits more healthy settlements, as Tapuro Ambir Hechuan, which is free of measles and other diseases, and where conditions seem even idyllic: "The children play happily and carefree, and adults work, rest and have fun in a happy"7 (p. $367 / 25$ Aug 1951). Darcy and his team stay there from 22 to 27 August 1951, and this photograph is taken during this period by the official SPI photographer, Heinz Förthmann.

As we have seen, Darcy often complains about the dirt and lack of hygiene but he seems scrubbed, freshly shaved, coiffured and perfumed, and in clean clothes. João Carvalho is also freshly shaved. The smiles, particularly Darcy's Cheshire Cat smile, may seem a little false. Are they the forced smiles of someone having an official photo taken, or is it part of Darcy's questioning technique, or does it come from his contentment at getting work successfully done with João Carvalho?

Darcy stands out in his freshly washed white clothes, which make him very much the outsider, probably a way of preserving some academic distance from his subjects in the foreign setting. He writes in the Diário that he does not attempt to dress like natives though admiring their nudity.

The photo is taken from an oblique angle, by professional photographer, but it deliberately appears unposed and even amateurish, with João Carvalho being partially cut off.

We see a formal interview, though we see nothing of the interviewee's face, in a formal interpreting situation, with tables and benches in a communal hut. Furniture was not part of native huts, and it seems the benches and tables have been rapidly improvised to help Darcy carry his official study and survey and write down details. But what is missing are the tools of Darcy's trade, his notebook, pen or pencil, and his sonograph, his

\footnotetext{
${ }^{6}$ Os mosquitos também me atormentam, é um suplício, já tenho todo o corpo marcado. Até inguas nas virilhas, que depois de muito me preocupar verifiquei serem consequência de tanta picada de insetos.

${ }^{7}$ As crianças brincam alegres e despreocupadas, os adultos trabalham, descansam e se divertem num ritmo feliz.
} 
voice recorded. As seen above, Darcy often complains he has nowhere to write. Now he does, but he is not writing. So maybe this is a staged photo just before the actual interview takes place, and Darcy is trying to put the interviewee at ease.

What are the other people doing there? Why does the other woman have her back turned? Is she next in the queue to be interviewed? What is she looking down at? Why has she been included in the photo? Who is the woman behind Darcy's left shoulder? Darcy remarks that the natives were always curious to know what he was doing and were often interrupting him, but this was more a case of the men than the women.

Maybe their presence is due to the very cramped facilities. All natives living under the same roof. Maybe they just had nowhere else to go. Everyone knows everyone else's business: "Every person who goes away from the village casually tells someone else where they are going. So, everyone knows, at any time, where everyone else is. This means that even outside the house, they are not only coexisting but living together, which is unbearable for people like us." 8 (p. 256 / 5 Mar 1950).

\section{Final Words}

Hopefully this study will lead to other works in an area - interpreters of indigenous peoples in Brazil - where no studies at all have been made. The same authors have recently written a study, still unpublished, on the interpreters of the SPI, focusing on the case studies of Vanuire, an indigenous woman interpreter who played a major role in the "pacification" of the Kaingang natives in the west of the São Paulo state in 1912, and the expeditions of Darcy Ribeiro and his use of interpreters to collect information on the Ka'apor groups in 1949 and 1951. Studies can be foreseen in a number of areas: the training of indigenous interpreters; the problems of interpreting particular languages or groups of languages; conference interpreting of in-

\footnotetext{
${ }^{8}$ Cada pessoa que se afasta conta a alguém, de passagem, para onde vai. Assim, todos sabem, a qualquer tempo, onde está cada um. Isso significa que, mesmo fora da convivência fora da casa, estão não apenas coexistindo, mas convivendo a vida toda, o que acaba por ser insuportável para gente como nós.
} 
digenous languages; and the possibilities of sign language interpreting in indigenous languages in Brazil. And of course, we can extend these suggestions to other Latin American countries.

Moreover, there are also many possibilities of examining photographs of interpreters in indigenous settings outside the SPI in Brazil and Latin America. For instance, some indigenous organizations such as APIB [Articulação dos Povos Indígenas do Brasil], FOIRN [Federação das Organizações indígenas do Rio Negro] and other regional and local ones have a broad archive in which you can see male and female interpreters in action. And as all the iphones are now fitted with video recorders the possibilities for research into indigenous interpreters are now infinite.

\section{References}

BARBOSA, Luiz Bueno Horta. A pacificação dos índios caingangue paulista. In: O problema indígena no Brasil. Rio de Janeiro: Imprensa Nacional, 1947. 72 p. (Comissão Rondon Publicação 88).

BARTHES, Roland. A Câmara Clara. tr. de La chambre claire: note sur la photographie, tr. Júlio Castañon Guimarães. Rio de Janeiro: Nova Fronteira,1980/2015.

FREIRE, Carlos Augusto da Rocha; GURAN, Milton. Primeiros Contatos: atrações e pacificações do SPI. Rio de Janeiro: Museu do Índio - FUNAI, 2010.

FREIRE, Carlos Augusto da Rocha (Org). Memória do SPI: textos, imagens e documentos sobre o Serviço de Proteção aos Índios (1910-1967). Rio de Janeiro: Museu do Índio - FUNAI, 2011.

EDWARDS, Elizabeth. Interpreting photographs: Some thoughts on method. In: Framing the Interpreter: Towards a visual perspective, ed. Anxo Fernández-Ocampo and Michaela Wolf. London: Routledge, 2014, p. 19-26. GOFFMAN, Erving. The Presentation of Self in Everyday Life. Harmondsworth: Penguin, 1959/1990.

KREES, Gunter; LEEUWEN, Theo van. Reading Images: The Grammar of Visual Design. 2nd ed. London: Routledge, 2006. 
LANGFORD, Rachael. Framing and Masking: Photographing the interpreter in/of colonial conflict. In: Framing the Interpreter: Towards a visual perspective, ed. Anexo Fernández-Ocampo and Michaela Wolf. London: Routledge, 2014, p. 39-50.

MERENCIO, Fabiana Terhaag. Artefatos Líticos da Subcoleção Loureiro Fernandes. Revista Tecnologia e Ambiente, Dossiê IX Reunião da Sociedade de Arqueologia Brasileira / Regional Sul, v. 21, n. 1, 2015, Criciúma, Santa Catarina, 2015.

MUSEU PARAENSE. Os Índios Xetá. http://www.museuparanaense.pr.gov.br/modules/conteudo/conteudo.php?conteudo=109. Accessed on 11 Jun. 2019.

PRATT, Mary Louise. Imperial Eyes: Travel Writing and Transculturation. New York: Routledge, 2008.

PREFEITURA MUNICIPAL DE DOURADINHA - PR. História. http://www.douradina.pr.gov.br/site/prefeitura/cidade/historia/. Acesso em 11 de junho de 2019.

PERES, Aline. 2007. Idioma xetá quase morre com Tuca. Índio era o que melhor dominava a língua - Aline Peres [12/06/2007]. Gazeta do Povo. https://www.gazetadopovo.com.br/vida-e-cidadania/idioma-xeta-quasemorre-com-tuca-aicylj3tdrd2oxr759fgijxou/. Accessed on 12 Jun. 2019. PINHEIRO, Niminon Suzel. Vanuíre: conquista, colonização e indigenismo: oeste paulista, 1912-1967. 292 f. PhD Thesis, Universidade Estadual Paulista, Faculdade de Ciências e Letras de Assis, 1999.

POVOS INDÍGENAS NO BRASILl. Xetá. Disponível em < https://www.indios.org.br/en/Povo:Xetá $\geq$. Accessed on 12 Jun. 2019.

SILVA, Carmen Lucia da. Sobreviventes do extermínio: uma etnografia das narrativas e lembranças da sociedade Xetá. PhD Thesis. Programa de Pósgraduação em Antropologia Social, Universidade de Brasília (UnB), 2005.

Loureiro Fernandes e os Xetá. Arqueologia, Número especial, Curitiba, v. 3, p. 197-216, 2005.

. Em Busca da Sociedade Perdida: O trabalho da memória Xetá. M.A. Dissertation. Centro de Filosofia e Ciências Humanas, Universidade Federal de Santa Catarina (UFSC), 1998. 


\begin{abstract}
Interpreting was one of the main strategies of the Indian Protection Service - SPI to "pacify" natives and integrate them into Brazilian society; within this scope, some interpreters deserve special attention for the role they played during the contact expeditions. This article investigates the performance of these interpreters through the analysis of the SPI photographic archive.
\end{abstract}

Keywords: History of Brazilian Interpreting; Indigenous Interpreter; Indian Protection Service; SPI.

\title{
Resumo
}

A interpretação foi uma das principais estratégias utilizadas pelo Serviço de Proteção aos Índios - SPI para "pacificar" indígenas e integrá-los à sociedade brasileira. Neste contexto, alguns intérpretes merecem atenção especial devido ao papel que desempenharam durante as expedições de contato. O presente artigo, assim, investiga a atuação destes intérpretes por meio da análise do arquivo fotográfico do SPI.

Palavras-chave: História da interpretação no Brasil; Intérprete indígena; Serviço de Proteção aos Índios; SPI. 